\title{
The new feminist frontier on community-based learning: popular feminism, online misogyny, and toxic masculinities
}

\author{
Rita Basílio Simões \\ University of Coimbra, Portugal (rbasilio@fl.uc.pt) \\ Inês Amaral \\ University of Coimbra, Portugal (ines.amaral@uc.pt) \\ Sofia José Santos \\ University of Coimbra, Portugal (sjs@ces.uc.pt)
}

\begin{abstract}
Feminist activism has always promoted informal learning opportunities for men and women. Internet, along with ICTs, has expanded these opportunities by affording largescale feminist mobilisation and connection. Yet, the digital environment is not only enhancing feminist campaigning but also facilitating the contexts for abusive behaviours to flourish. Departing from the concept of social movement learning, we examine the significance of the large-scale reinvigoration of feminist activism to adult education in tandem with the surge of anti-feminist and misogynist ideas in the digital environment. We argue that just as online social media brought unprecedented opportunities to provide social movement learning, it offered the same tools to misogynists groups, mostly led by a toxic understanding of masculinity. By co-opting the same online opportunities the feminist movement enjoys, individualised and collective toxic masculinity agency is a potential foe to match, not only adding advantage to feminist movements but reinventing the same struggle and demanding an ongoing battle towards deconstructing patriarchy.
\end{abstract}

Keywords: Adult education, Digital feminist activism, Misogyny, Social movement learning, Toxic masculinities 


\section{Introduction}

By shedding light on unequal gender norms and the relational nature of gender while putting forward gender-equal agendas, women's movements on feminist issues have always promoted informal learning opportunities for adult people. Through campaigns on women's political rights or on the need to engage men in domestic work and caregiving, feminism has created numerous opportunities to share knowledge, give voice to the voiceless and encourage the engagement of the community towards gender equality. In a nutshell, feminist movements have provided what is widely coined as "Social movement learning". This non-formal education practice is key in fostering social change as people engage in social movement practices and learn with experience while fostering the causes that are promoted (Hall \& Clover, 2005). From street protests on women's sexual and reproductive rights to media campaigns against domestic violence or sexual harassment, learning about gender inequality has always happened at the intersection between significant life experiences and the knowledge shared. This knowledge, encompassing the language and the imagery for expressing complaints, are no longer solely dependent of the mainstream media, with whom feminist movements have always had a tense relation (Thornham, 2007; Faludi, 1991; Hollows, 2000; Gill, 2007; 2016; McRobbie, 2009).

The Internet, along with information and communication technologies (ICTs), has expanded these opportunities greatly. Across digital platforms, individuals address experiences relating to sexism, misogyny, and violence, frequently "shouting back" in response to prejudice (Turley \& Fisher, 2018), while organisations campaign against patriarchy and inequality in favour of women's rights (Matos, 2017). Digital media practices, which provide collective and connective feminist discussions, embody political and pedagogical tools (Fotopoulou, 2016). Academically, these trends invited scholars to rethink political feminist action (Mendes, Ringrose, \& Keller, 2018; Mendes, 2019; Nuñez Puente, D’Antonio Maceiras, \& Fernández Romero, 2019), mainly focusing upon how digital platforms may assist feminism and how power and resources may indeed be redistributed and balanced through digital platforms as new and accessible ways of political expression arise. However, on par with the possibilities the digital environment offers feminist action, digital platforms have also created new opportunities for sexism and misogynist ideas to spread outward across different platforms (Banet-Weiser, 2015). In point of fact, the articulation between easy access to the Internet, on the one hand, and smartphones equipped with different types of technological tools and social media applications, on the other, provided new online facilitating contexts to abusive behaviours, frequently in response to an ongoing conversation, causing harm, compromising feminist messages and fostering toxic environments (Citron, 2014; BanetWeiser \& Miltner, 2016; Turley \& Fisher, 2018; Marwick \& Caplan, 2018; Harrington, 2020).

Based upon this literature, this article focusses on the conditions the online enhances social movement learning for adult education in today's gender-based activism, specifically feminist online activism and "manospheres" collections of websites, blogs, and online forums promoting some forms of masculinity and hostility towards women.

The same strengths that make online feminism successful in social movement learning, i.e., connecting, giving account, making individual stories to become collective political action and providing alternative forms of justice is, we argue, the same ones that allow online misogyny to be effective concerning mobilisation and non-formal education. To advance this argument, this paper is structured into three sections. The first section is dedicated to feminism and social movement learning, exploring how feminism as a social 
movement has, since its inception, mobilised, engaged and created collective action, while providing social movement learning. The second section is focused on how the digital realm provided unparalleled tools for feminism to expand and connect beyond core activists, setting in motion social movement learning. The third section explores how through co-opting the same online strategies that feminist movements use, individualised and collective toxic masculinity agencies are a potential foe to match, reinventing the same struggle - with different tools, but still equally accessible to both sides.

\section{Feminism and social movement learning}

Social movements tend to put forward political action towards social transformation through mobilisation, contestation, awareness-raising, and also informal learning. Feminism as a social movement is no exception to these trends. Social movements in structuralist and post-structuralist models (Polleta \& Jasper, 2001) are conceptualised from a "collective identity" perspective, an approach intrinsically linked to the idea of "collective action" (Nunes, 2014). Melucci (1995, p. 43) considers 'collective action as the result of purposes, resources, and limits, as a purposive orientation constructed by means of social relationships within a system of opportunities and constraints'. Therefore, the author argues that:

collective identity is an interactive and shared definition produced by several individuals (or groups at a more complex level) and concerned with the orientations of action and the field of opportunities and constraints in which the action takes place. By 'interactive and shared' I mean a definition that must be conceived as a process because it is constructed and negotiated through a repeated activation of the relationships that link individuals (or groups) (Melucci, 1995, p. 44).

Participation stems from civic agency, which involves the civic engagement of citizens in issues of public and political life (Dahlgren \& Álvares, 2014). When theorising the notion of civic participation, several authors emphasise the emergence of individualised engagement actions and new styles of citizenship induced by technological, social and economic changes (Barnidge, Macafee, Alvarez, \& Rojas, 2014; Bennett, 2008; Bennett $\&$ Segerberg, 2011). Citizenship and engagement are a direct consequence of different communication patterns (online and offline) that influence individuals to have specific behaviours concerning civic participation (Barnidge et al., 2014) within social movements and connective networks (Bennett \& Segerberg, 2012).

Carpentier's (2011) definition of participation refers to an approach of minimalist and maximalist political-democratic models. The author argues that macro-participation refers to participation and political imagined communities, while micro-participation occurs in small spheres of everyday life (Carpentier, 2011). In this regard, Soon (2013, p. 200) observes that 'macro-level and micro-level approaches have been used to determine conditions that influence successful mobilisation, collective action participation and the threshold or tipping point when one crosses from non-participation to participation'.

Following critical adult education theory (Freire, 1970; Foley, 1999; Choudry, 2015; Choudry \& Vally, 2017), this paper contends that adult education should attend to connections between education and learning, communities of practice, and emancipatory struggles (Choudry et al., 2017). Therefore, political and contentious action movements are spaces that promote informal and non-formal learning of knowledge produced from people's daily experience in collective and emancipatory struggles (Choudry et al., 2017). 
A growing field of study in adult education, social movement learning, focuses on the 'learning that occurs within social movements and because of social movements' (Walker \& Palacios, 2016, p. 176). As 'epistemic communities' (Eyerman \& Jamison, 1991, p. $10)$, social movements are privileged sites for the promotion of new knowledge through new understandings of different issues (Hall et al., 2005, p. 584). Therefore, social movement learning offers the opportunity for non-formal and informal learning networks. As participation environments par excellence, social movements enhance learning by people who integrate them, as well as to external individuals as a result of the actions carried out or for the causes that they promote (Hall et al., 2005).

Formal learning focuses on individual subjects and takes place within an institutional environment credited by competent bodies. Non-formal education takes place outside the scope of formal learning and develops in a socio-educational way that considers problems and issues inserted in social, cultural and political contexts. In informal education, learning occurs spontaneously, not systematised and not organised.

Considering a neutralisation of the social aspects of learning (Cunningham, 1998), social movements promote a collective perspective of non-formal and informal learning. In fact, 'from the social movement perspective it is formal education that produces vague outcomes, because it rarely results in tangible collective action that seeks to make real differences in people's lives' (Zielińska, Kowzan, \& Prusinowska, 2011, p. 252).

Traditionally, social movements have always been anchored to social struggles and a collective identity through which negotiation processes were designed (Melucci, 1995). In a different logic from unionised or rural movements, the 'new movements' are mainly urban and shape the reconfiguration of societies (Magalhães, Marôpo, \& Amaral, 2018). The so-called "new social movements" are comprehensive and fit the pacifist, environmentalist, civil and women's rights movements, among others (Magalhães et al., 2018). These movements are presented as 'catalysts for personal transformation and the environment within which transformation occurs' (Hall et al., 2005, p. 585).

In the European tradition, adult education is linked to the emergence of the first social movements such as labour, the struggle for women's rights to vote or the fight against poverty (Hall et al., 2005). The learning theory of social movements considers that learning from its political dimension, allowing the democratic right of learning for everyone and the world (Finger \& Asún, 2001). Furthermore, this theory focuses on the context of endogenous knowledge, as opposed to the perspectives of formal education as an exogenous knowledge transmission system (Finger et al., 2001). As Choudry and Vally (2017, p. 3) stated, 'movements are not only significant sites of social and political action, but also important, albeit contested and contradictory, terrains of learning and knowledge production'.

Engaging with Marxist, feminist, anti-racist and anti-colonial perspectives, Choudry (2015) states that activist research and anti-capitalist and anti-globalization movements are often mutually constitutive. The author contends a dialectical relationship between the knowledge produced in these movements and the material conditions experienced in social and economic justice struggles. Foley (1999) claims that informal learning occurs in social action. Welton (1993) argues that the 'new social movements' are privileged spaces for emancipatory and transformative teaching practices. It is from this perspective that feminism is interconnected with the theory of social movement learning, as the concept of resistance prevails and provides a point of engagement to learn (English \& Irving, 2015).

Feminist organisations are places of informal and non-formal learning, where citizens learn advocacy, literacy and social democratic practices. As Irving and English (2011) emphasise, feminist social action groups of the 1970s have created well- 
established community-based women's resource centres that promote learning through activism.

Feminist social movement learning promotes transformative learning. By taking into account the collective learning through social action, feminist social movement learning refers to a). women's non-formal and informal learning in women's movements and personal and social experience in that context; b). a reorientation of social action considering feminist ideals; c). learning pedagogies that are traditionally associated with the feminine (Walker \& Butterwick, 2019).

As Walker and Butterwick (2019, p. 477) argue:

\begin{abstract}
A feminist social movement learning is about content and process. In content, it means learning about the various women's movements, and women activists, from today and from the feminist movements of eras past; it is about learning from those women activists who lived through these decades of activism of the latter part of the 20th century. In process, it is about paying conscious attention to the types of learning we undergo through involvement in all social movements, feminist and otherwise, that privilege both informal learning more generally, and the embodied, experiential, affective, and artistic ways of knowing, learning, and teaching more specifically.
\end{abstract}

Feminist social movement learning scholarship enhances the place of feminism in adult education by social struggle. The connection between adult education and feminist action has a long tradition that goes back to decades of struggles for equality and social justice. It is within this context of "feminist consciousness-raising circles" (Walker et al., 2019, p. 473) that the shared experience of women in activist movements becomes relevant. Women learnt from each other about human rights, gender equality and social justice. Adherence to the struggles for voting and emancipation results from these non-formal and informal learning promoted by early women's movements. Advances in women's sexual and reproductive rights derive from this link between feminist action and adult education. It is also in this context that decades of silence on sexual violence and sexual harassment begin to give rise to public complaints and the sharing of experiences in order to support and help victims.

The anti-racist feminist theory argues the need to politicise personal experience (Gouin, 2009), assuming itself as a criticism of Foley's (1999) that does ignore gender, race, class and sexual orientation. In fact, 'community-based feminist organisations represent socially and economically marginalised people and are often located in a marginalised space themselves within the nonprofit world' (Irving et al., 2011, p. 263). Gouin claims for a gendered and intersectional understanding of social movements learning.

Since the 1990s, feminist organisations and women's movements have focused on the use of ICTs to promote technology-mediated learning and intensify feminist activism.

Hoobs and Coiro (2016) argue that collaborative learning processes are crucial concerning the development of critical thinking. As Freire (1997, p. 50) argued:

if it were clear to us that it was by learning that we learned that it was possible to teach, we would have easily understood the importance of informal experiences in the streets, in the squares, at work, in school classrooms, in the playgrounds [...] in which various gestures $[\ldots]$ intersect full of meaning.

Within communication for development (C4D), promotion of a critical reading of the world (Freire \& Macedo, 2011) based on dialogue for social change is the basis to facilitate 'the functions of democratizing public opinion, empowering people and mobilizing for a common issue' (Brites, Amaral, \& Catarino, 2018, p. 91). 
Social change is anchored in a process in which technology is a cultural, economic and political instrument (Castells \& Catterall, 2001). Media hybridization and technological innovations directly influence the social sphere (Amaral, 2019). Therefore, online environments allow the appropriation of affordances from different media and platforms, creating new spaces for formal, informal and non-formal learning for adults. Indeed, 'the potential of social media for C4D purposes is being increasingly recognized and explored since social networks have multiplied the diversity of communication channels and opportunities for the public' (Jenatsch \& Bauer, 2016, p. 30). In this line of reasoning, digital skills are associated with civic competencies, which combines digital literacy with media literacy and citizen participation (Jover, Martín, \& Fuentes, 2015).

\section{Online activism and popular feminism}

The online realm provides unparalleled conditions for feminism to put forward social movement learning. Social media allows individuals to give an account of their own stories and to make those stories connect with other similar ones, making individual stories to become a collective political agenda (Clark-Parsons, 2019) thereby providing a sense of restorative justice. As such, they provide social movement learning at different scales, engaging diverse audiences. Studies show that the digital environment has fundamentally increased the surge and widespread of activism as the interaction and dissemination logic of online media, particularly social media, has created unrivalled conditions to intensify the flow and efficiency of specific ideologies (Amaral, 2020). Based upon a "Facebook disclosure" logic (Rochlin, 2017), social media promote contents and information diets increasingly guided and endorsed by personal beliefs and emotions (Giuliani, Garraio, \& Santos, 2019; Rochlin, 2017), and the feeling of belonging to a group with similar opinions appears as a mobilising element of collective actions (Bakardjieva, 2015). Each post constitutes an "individualised collective action" (Micheletti, 2003), which means a spontaneous action that may (or may not) fit, despite lacking any organisation, into wider connective actions (Bennett et al., 2011), contributing to the increasing of the flow and the political agenda endorsed by the flow (Amaral \& Santos, 2019).

Social media platforms help to disseminate non-institutionalised versions of social reality, as users publicly disclose their ideas and everyday knowledge. Also, digital media practices can be, at the same time, political and pedagogical (Fotopoulou, 2016). Power and resources are symbolically redistributed and balanced through digital media as new ways of political expression, and news claims for recognition arise, pushing forward social change. But they also represent a materialist effect, empowering citizens to work together on networks of solidarity across national borders, affording them to experiment and learn with technologies and ideas.

Against the backdrop of the feminist backlash of the 1990s (Faludi, 1991), and the more recent thesis of the quasi-abandonment of feminist issues in the popular media (Gill, 2007; McRobbie, 2009), there has been a renewed interest in feminist politics across many countries worldwide, particularly in the last couple of years. Extensive prominence of feminism in an array of mainstream media has burgeoned as the movement succeeded in mobilising different audiences and encouraging women to focus on self-empowerment and personal aspirations (Banet-Weiser, 2018; Rottenberg, 2018). Transnational online feminist movements also became very visible and have brought into the spotlight different types of feminist activism and advocacy. Indeed, scholars have identified the potential of social media activism to raise and expand awareness about a myriad of issues related to 
patriarchy, sexism, and gender-based violence along with the drawbacks that it presents (Citron, 2014; Banet-Weiser et al., 2016; Turley et al., 2018; Harrington, 2020). Some academic literature and opinion-editorials (Munro, 2013; Guillard, 2016) have seen these technology-based movements as enacting an authentic "fourth wave" of feminist practice. Others (Youngs, 2005) have equated the digital era as a mere new phase for feminism in theory and practice. Online horizontal networks and activities allow activists to directly enroll and extend knowledge, building across national boundaries. However, shortcomings and ongoing challenges prevent us from coining these technological movements as a fourth wave.

Digital technology has been indeed offering unprecedented possibilities for reimagining political engagement, given its potential to be immediate, intrinsically participatory (Dahlgren, 2009) and encompassing cross-border collaborative associations (Castells, 2000). As a result, this new environment has "disrupted historical masculinist constraints on women's political presence and engagement" (Youngs, 2015, p. 858) while allowing women's organisations and activists to enroll in non-established practices, communication strategies and repertoires of action (Fotopoulou, 2016; Mendes et al., 2018; Matos, 2019). It thus allowed for women to have space to give an account of their own stories without having to go through the mediation of mainstream media, where genderised harms are often contested (Silveirinha, Simões, \& Filgueiras, 2019). It also allowed women to feed a collective political agenda (Clark-Parsons, 2019), creating the momentum and the tools to provide social movement learning reaching out to different audiences.

Social media platforms, in particular, have been described as playing essential roles in the domain of alternative politics. As the formal system appears to fail in preventing gender-based violence, protecting victims and overcome structural patriarchy, social media-based campaigns on violence, sexism and inequality emerge as an arena for groups and individuals to protest, mobilise for collective action, as well as for victims to share their personal experiences at different levels, find alternative forms of justice and different forms of educating for gender equality (Mendes, 2019; Núñez Puente, D’Antonio Maceiras \& Fernández Romero, 2019). Innovative forms of transnational mobilisation, based on cross-border networks, have linked local, national, regional and international agendas (Harcourt, 2013), and helped as well to send the message out while also engaging and creating the platforms and means for social learning. By fostering to fight against different kinds of oppression, social media activist within the digital realm seem to be mobilising unprecedented practices even to overcome internal tensions as represented by the non-western-white-feminism (Brown, Ray, Summers, \& Fraistat, 2017) or reaching out to those unfamiliar with feminism.

\section{Facing drawbacks: sexism and misogyny}

Online and offline realms are not detached one from the other but somewhat convergent and mutually reinforcing (Rogers, 2004). That is why, over the past decade - and somehow unsurprisingly, as the so-called "digital era" flourished and consolidated in everyday practices, and "cultural backlash" gained momentum -, expressions of misogynist beliefs started likewise to emerge in the online realm, providing, in turn, their own social movement learning. The popularisation of feminist critique of hegemonic discourses took advantage of digital platforms affordances but has met new encounters with anti-feminist positions which may be dismissing political feminist action. As feminism gained new visibility, online and offline (Gill, 2016), misogyny was also 
brought into the spotlight, shouting back the need to challenge the patriarchal and societal systems. That is why, for Sarah Banet-Weiser (2015), "popular misogyny" embodies a "call and response" dynamic towards popular feminism.

Although sexist, misogyny is not a male-exclusive trait/phenomena. Much of this contempt against women and girls has been put forward by men and women, framed and legitimised by patriarchal frameworks and beliefs. However, misogyny, whenever led by men, is in part driven and sustained by a particular socially destructive embodiment of masculinity - "toxic masculinity" with particularly harmful consequences concerning social movement learning. This intensified harm has to do, we argue, with the exact same strengths that make online feminism effective in social movement learning, i.e., connecting, giving account, making individual stories to become collective political action.

Toxic masculinity is phrased as such so that both its violence-based features and harmful consequences are highlighted. Toxic masculinity is indeed built upon the specific elements of hegemonic masculinity 'that foster domination of others' (Kupers, 2005, p. 717). As behaviour and attitude, it is expressed through 'a strong need to dominate and control others', 'a readiness to resort to violence, and the stigmatisation and subjugation of women, gays, and men who exhibit feminine characteristics' (Kupers, 2005, p. 717). Domestic violence, harassment, gender-based rhetorical violence or sexual violence are a few concrete expressions of what can be perceived and labelled as toxic masculinity.

On par with male misogynist individualised agency, there has also been a growth of so-called "Men's movements", i.e., an informal and loose network of individuals and groups who share the belief that men are victims of women and need, therefore, to be rescued from an ongoing "feminist delusion" (Ging, 2019, p. 638). This collective online misogynist agency became increasingly present and visible in online blogs and social media constituting what the literature labels as the "manosphere" (Ribeiro et al., 2020). Within the manosphere, newer communities, such as the Incels or Men Going Their Own 'are more toxic and misogynistic than the older ones', namely Pick Up Artists and Men's Rights Activists (Ribeiro et al., 2020, p. 10). Their motivation is based upon a need to account for their stories, to connect to other alleged victims of feminist beliefs and frameworks, and, hence, be given restorative justice and mobilise through social movement learning towards political action (Ribeiro et al., 2020; Ging, 2019) - formally and in everyday practices.

Misogynist rhetoric also normalises violence against women (Banet-Weiser et al., 2016). Feminist research has made it clear that digital platforms reproduce offline dominant gender norms and facilitate new ways of undertaking violence, in the process making it part of everyday practices (Sundén \& Paasonen, 2018). From newspaper comment sections to social networking profiles, blogs and forum, women are repeatedly subjected to harassment, insults, and different kind of expressions of online abuse (Marwick \& Miller, 2014; Ben-David \& Matamoros-Fernández, 2016; Crawford \& Gillespie, 2016; Jane, 2017; Massanari, 2017).

Different linguistic formulae are used to name the violent behaviours, such as "online sexist hate", "online misogyny", "gender trolling" or "online harassment". All of them correspond to constellations of offensive behaviour practised using digital platforms that involve 'the intentional imposition of substantial emotional suffering, through online discourse', which is never an isolated incident, but, rather, a persistent behaviour (Citron, 2014, p. 3). Attacks are amplified by the feeling of anonymity and impunity and are frequently directed to women airing their views and experiences relating to inequality and sexism or who identify as feminists (Jane, 2017). Defying the status quo is thus being placed in a risky position of suffering an online attack. Also, as the scrutiny of the female 
body increases, so the abuse through the non-consensual sharing of sexual images has flourished, damaging not only the victims' rights to privacy but also the victims' sexual integrity (McGlynn, Rackley, \& Houghton, 2017).

Online sexist and misogynistic behaviours can be thus viewed as part of the continuum of violence against women (Kelly, 1988). It stands for a larger culture that values men's sexually predatory behaviours and sexual assault against women, as well as women's subordination and marginalisation in sexual life as is key in the political, economic, and social fields (Simões \& Silveirinha, 2019). These behaviours are, routinely trivialised in daily discourses and practices, which frequently blame the victims, excuse the perpetrators and naturalise violence as a normal practice online (Penny, 2013).

Sexist and misogynist rhetoric disclaims discourses of female empowerment as damaging to men's rights (Marwick \& Caplan, 2018), alerting feminists to consider both the digital possibilities afforded by digital feminist activism as well as the challenges it faces. The role played by the term "misandry" in different online "manosphere spaces" exemplifies the problematic link between online misogyny and feminist advocacy. As Marwick and Caplan (2018, p. 544) contend, the term 'encapsulates a theory of feminism as intrinsically prejudicial and threatening toward men, which provides justification for networked harassment of those espousing feminist ideas'.

\section{Conclusion: Ongoing social movement deconstruction, ongoing social movement learning}

Celebratory perspectives on the role and opportunity of the digital environment for social movement learning concerning feminism was challenged by the emerging misogynists online movements, mostly led by men inspired by a toxic understanding of what it means to be and behave like a "real man". The conditions of vulnerability of women digital participation, which is also/still subject to misogynist rhetoric, gender trolling, offences and abuses, put into perspective the emancipatory promise of the new digital environment as a place of individual liberation and democratic renewal. At the same time, as the digital realm provides unparalleled opportunities to a horizontal and democratising social movement learning, it offers the exact same possibilities to misogynists groups. As such, online reinvents ongoing emancipatory potential and struggles, reinforcing the need for a continuous deconstruction of patriarchy.

This paper intended to explore how the online realm empowers feminism while at the same time giving misogynist movements the same conditions to thrive. As the paper discussed, the exact same strengths that make online feminism successful in social movement learning (i.e., connecting, giving account, making individual stories to become collective political action and providing restorative justice) is the one that allows online misogyny to be effective concerning mobilisation and subsequent social movement learning. Although the extent to which online misogyny is affecting digital platforms credibility as facilitators of learning requires further analysis, the dialectic nature of the digital realm expresses and sheds light on the need to envisage feminist struggle as an ongoing work concerning the deconstruction of patriarchy and the (re)construction and (re)negotiation of gender norms towards an emancipatory understanding and practice of gender roles and identities. 


\section{Acknowledgements}

Financial support from Portuguese national funds through FCT (Fundação para a Ciência e a Tecnologia) in the framework of the project "Online Violence Against Women: preventing and combating misogyny and violence in a digital context from the experience of the COVID-19 pandemic" (Reference GENDER RESEARCH 4 COVID-19-058) and the Project "(De)Coding Masculinities: Towards an enhanced understanding of media's role in shaping perceptions of masculinities in Portugal" (Reference PTDC/COMCSS/31740/2017).

\section{References}

Amaral, I. (2019). Transmedia storytelling e literacia: histórias multimédia participativas. In M. J. Brites, I. Amaral, \& M. T. Silva (Eds.), Literacias cívicas e críticas: refletir e praticar (pp. 43-57). Braga: CECS.

Amaral, I., \& Santos, S. J. (2019). Algoritmos e redes sociais: A propagação de fake news na era da pósverdade. In J. Figueira \& S. Santos (Eds.), As fake news e a nova ordem (des)informativa na era da pós-verdade (pp. 63-85). Coimbra: Imprensa da Universidade de Coimbra. https://doi.org/10.14195/978-989-26-1778-7

Amaral, I. (2020). Citizens beyond Troika: Media and anti-austerity protests in Portugal. International Journal of Communication, 14(21), 3309-3329. https://doi.org/1932-8036/20200005

Bakardjieva, M. (2015). Do clouds have politics? Collective actors in social media land. Information, Communication \& Society, 18(8), 983-990. https://doi.org/10.1080/1369118X.2015.1043320

Banet-Weiser, S. (2015). 'Confidence you can carry!': Girls in crisis and the market for girls' empowerment organisations. Continuum, 29(2), 182-193. https://doi.org/10.1080/10304312.2015.1022938

Banet-Weiser, S., \& Miltner, K. (2016). \# MasculinitySoFragile: Culture, structure, and networked misogyny. Feminist Media Studies, 16(1): 171-174. https://doi.org/10.1080/14680777.2016.1120490

Banet-Weiser, S. (2018). Empowered: Popular feminism and popular misogyny. Durham: Duke University Press.

Barnidge, M., Macafee, T., Alvarez, G., \& Rojas, H. (2014). Citizenship and political participation in Colombia: How orientations toward citizenship associate with political and civic behaviors. International Journal of Communication (8)20, 1831-1850. https://doi.org/1932-8036/20140005

Ben-David, A., \& Matamoros Fernández, A. (2016). Hate speech and covert discrimination on social media: Monitoring the Facebook pages of extreme-right political parties in Spain. International Journal of Communication, 10, 1167-1193. https://doi.org/1932-8036/20160005

Bennett, W. L. (2008). Changing citizenship in the digital age. In W. L. Bennett (ed.), Civic life online: Learning how digital media can engage youth (pp. 1-24). Cambridge: MIT Press.

Bennett, W. L., \& Segerberg, A. (2011). Digital media and the personalisation of collective action. Information Communication and Society, 14(6), 770-799. https://doi.org/10.1080/1369118X.2011.579141

Bennett, W. L., \& Segerberg, A. (2012). The logic of connective action: Digital media and the personalisation of contentious politics. Information, Communication \& Society, 15(5), 739-768. https://doi.org/10.1080/1369118X.2012.670661

Brites, M. J., Amaral, I., \& Catarino, F. (2018). A era das "fake news": o digital storytelling como promotor do pensamento crítico. Journal of Digital Media \& Interaction, 1(1), 85-98.

Brown, M., Ray, R., Summers, E., \& Fraistat, N. (2017). \# SayHerName: A case study of intersectional social media activism. Ethnic and Racial Studies, 40(11), 1831-1846. https://doi.org/10.1080/01419870.2017.1334934

Carpentier, N. (2011). Media and participation: A site of ideological-democratic struggle. Bristol: Intellect Ltd.

Castells, M. (2000). Toward a sociology of the network society. Contemporary Sociology, 29(5), 693699. https://doi.org/10.2307/2655234

Castells, M., \& Catterall, B. (2001). The making of the network society. London: Institute of Contemporary Arts. 
Choudry, A. (2015). Learning Activism: The Intellectual Life of Contemporary Social Movements. Toronto: University of Toronto Press.

Choudry, A., \& Vally, S. (Eds.). (2017). Reflections on knowledge, learning and social movements: History's schools. Oxon \& New York: Routledge.

Citron, D. K. (2014). Hate crimes in cyberspace. Harvard: Harvard University Press.

Clark-Parsons, R. (2019). "I see you, I believe you, I stand with you":\# MeToo and the performance of networked feminist visibility. Feminist Media Studies, 1-19. https://doi.org/10.1080/14680777.2019.1628797

Crawford, K., \& Gillespie, T. (2016). What is a flag for? Social media reporting tools and the vocabulary of complaint. New Media \& Society, 18(3), 410-428. https://doi.org/10.1177/1461444814543163

Cunningham, P. M. (1998). The social dimension of transformative learning. PAACE Journal of Lifelong Learning, 7, 15-28.

Dahlgren, P. (2009). Media and political engagement: Citizens, communication, and democracy. Cambridge: Cambridge University Press.

Dahlgren, P., \& Álvares, C. (2014). Political participation in an age of mediatisation: Towards a new research agenda. Javnost-the Public, 20(2), 47-65. https://doi.org/10.1080/13183222.2013.11009114

English, L. M., \& Irving, C. J. (2015). Feminism in community: Adult education for transformation. Lieden: Brill Sense.

Eyerman, R., \& Jamison, A. (1991). Social movements: A cognitive approach. University Park, PA: Pennsylvania State University Press.

Faludi, S. (1991). Backlash: The undeclared war against American women. New York: Three River Press.

Finger, M., \& Asún, J. M. (2001). Adult education at the crossroads: Learning our way out. London: Zed Books.

Foley, G. (1999). Learning in social action: A contribution to understanding informal education. London: Zed Books.

Fotopoulou, A. (2016). Feminist activism and digital networks: Between empowerment and vulnerability. London: Palgrave Macmillan.

Freire, P. (1970). Pedagogy of the Oppressed. New York: Continuum.

Freire, P. (1997). Pedagogia da Autonomia: saberes necessários à prática educativa. São Paulo: Paz e Terra.

Freire, P., \& Macedo, D. (2011). Alfabetização : leitura do mundo, leitura da palavra. São Paulo: Editora Villa das Letras.

Gill, R. (2007). Postfeminist media culture: Elements of a sensibility. European Journal of Cultural Studies, 10(2), 147-166. https://10.1177/1367549407075898

Gill, R. (2016). Post-postfeminism?: New feminist visibilities in postfeminist times. Feminist Media Studies, 16(4), 610-630. https://10.1080/14680777.2016.1193293

Ging, D. (2019). Alphas, Betas, and Incels: Theorising the masculinities of the manosphere. Men and Masculinities, 22(4), 638-657. https://doi.org/10.1177/1097184X17706401

Giuliani, G., Santos, S. J., \& Garraio, J. (2019). Online social media and the construction of sexual moral panic around migrants in Europe. Socioscapes - International Journal of Societies, Politics and Cultures, 1(1), 161-180.

Gouin, R. (2009). An antiracist feminist analysis for the study of learning in social struggle. Adult Education Quarterly, 59(2), 158-175. https://doi.org/10.1177\%2F0741713608327370

Guillard, J. (2016). Is feminism trending? Pedagogical approaches to countering (Sl)activism. Gender and Education, 28(5), 609-626. https://10.1080/09540253.2015.1123227

Hall, B. L., \& Clover, D. (2005). Social movement learning. International Encyclopedia of Adult Education, 584-589.

Harcourt, W. (2013). Body politics in development: Critical debates in gender and development. New York: Zed Books Ltd.

Harrington, C. (2020). Popular feminist websites, intimate publics, and feminist knowledge about sexual violence. Feminist Media Studies, 20(2), 168-184. https://10.1080/14680777.2018.1546215

Hobbs, R., \& Coiro, J. (2016). Everyone learns from everyone: Collaborative and interdisciplinary professional development in digital literacy. Journal of Adolescent \& Adult Literacy, 59(6), 1-7. https://doi.org/10.1002/jaal.502

Hollows, J. (2000). Feminism, femininity and popular culture. Manchester, New York: Manchester University Press. 
Irving, C. J., \& English, L. M. (2011). Community in cyberspace: Gender, social movement learning, and the Internet. Adult Education Quarterly, 61(3), 262-278. https://doi.org/10.1177\%2F0741713610380448

Jane, E. A. (2017). Systemic misogyny exposed: Translating rapeglish from the manosphere with a random rape threat generator. International Journal of Cultural Studies, 21(6), 661-680. https://doi.org/10.1177/1367877917734042

Jenatsch, T., \& Bauer, R. (2016). Communication for development: A practical guide. Bern: Federal Department of Foreign Affairs and Swiss Agency for Development and Cooperation.

Jover, G., González Martín, M. D. R. \& Fuentes, J. L. (2015). Exploración de nuevas vías de construcción mediática de la ciudadanía en la escuela: De Antígona a la narrativa transmedia. Teoría de la Educación. Revista Interuniversitaria, 27(1), 69-84. https://doi.org/10.14201/teoredu20152716984

Kelly, L. (1988). Surviving sexual violence. Cambridge: Polity Press.

Kupers, T. A. (2005). Toxic masculinity as a barrier to mental health treatment in prison. Journal of Clinical Psychology, 61(6), 13-724. https://doi.org/10.1002/jclp.20105

Magalhães, M., Marôpo, L., \& Amaral, I. (2018). Ativismo feminista no Facebook: Uma análise comparada das páginas Não me Kahlo (Brasil) e Capazes (Portugal). Mediapolis - Revista de Comunicação, Jornalismo e Espaço Público(7), 31-46. https://doi.org/10.14195/2183-6019_7_2

Marwick, A. E., \& Miller, R. (2014). Online harassment, defamation, and hateful speech: A primer of the legal landscape. Fordham Center on Law and Information Policy Report, (2). Retrieved May 7, 2021, from https://ssrn.com/abstract=2447904

Marwick, A. E., \& Caplan, C. (2018). Drinking male tears: Language, the manosphere, and networked harassment. Feminist Media Studies, 18(4), 543-559. https://10.1080/14680777.2018.1450568

Massanari, A. (2017). \#Gamergate and the Fappening: How Reddit's algorithm, governance, and culture support toxic technocultures. New Media \& Society, 19(3) 329-346. https://doi.org/10.1177/1461444815608807

Matos, C. (2017). New Brazilian feminisms and online networks: Cyberfeminism, protest and the female 'Arab Spring'. International Sociology, 32(3) 417-434. https://doi.org/10.1177/0268580917694971

Matos, C. (2019). Feminist media studies across borders: Re-visiting studies within the Brazilian national context. Journal of International Women's Studies, 20(2), 11-25.

McGlynn, C., Rackley, E., \& Houghton, R. (2017). Beyond 'revenge porn': The continuum of imagebased sexual abuse. Feminist Legal Studies, 25(1), 25-46. https://doi.org/10.1007/s10691-0179343-2

McRobbie, A. (2009). The aftermath of feminism: Gender, culture and social change. Los Angeles, CA; London; New Delhi, India; Singapore; Washington, DC: SAGE.

Melucci, A. (1995). The process of collective identity. In H. Johnston \& B. Klandermans (Eds.), Social movements and culture (pp. 41-63). Minneapolis: University of Minnesota Press.

Mendes, K., Ringrose, J., \& Keller, J. (2018). \#MeToo and the promise and pitfalls of challenging rape culture through digital feminist activism. European Journal of Women's Studies, 25(2), $236-246$. https://10.1177/1350506818765318

Mendes, K. (2019). Digitised narratives of sexual violence: Making sexual violence felt and known through digital disclosures. New Media \& Society, 21(6) 1290-1310. https://doi.org/10.1177/1461444818820069

Micheletti, M. (2003). Shopping with and for virtues. In M. Micheletti (Ed.), Political virtue and shopping (pp. 149-168). New York: Palgrave Macmillan.

Munro, E. (2013). Feminism: A fourth wave?. Political Insight, 4(2), 22-25. https://doi.org/10.1111/2041-9066.12021

Nunes, C. (2014). The social movement concept under debate: From the sixties to the present day. Sociologia, Problemas e Práticas (75), 131-147. https://doi.org/10.7458/SPP2014753579

Núñez Puente, S., D’Antonio Maceiras, S., \& Fernández Romero, D. (2019). Twitter activism and ethical witnessing: Possibilities and challenges of feminist politics against gender-based violence. Social Science Computer Review, 1-17. https://doi.org/10.1177/0894439319864898

Penny, L. (2013). Cybersexism: Sex, gender and power on the Internet. London, New Delhi, New York, Sydney: Bloomsbury.

Polletta, F., \& Jasper, J. M. (2001). Collective identity and social movements. Annual Review of Sociology, 27(1), 283-305. https://doi.org/10.1146/annurev.soc.27.1.283

Ribeiro, M. H., Blackburn, J., Bradlyn, B., De Cristofaro, E., Stringhini, G., Long, S., Greenber, S., \& Zannettou, S. (2020). The evolution of the manosphere across the Web. arXiv preprint arXiv:2001.07600. Retrieved May 7, 2021, from http://arxiv.org/abs/2001.07600 
Rochlin, N. (2017). Fake news: belief in post-truth. Library Hi Tech, 35(3), 386392.https://doi.org/10.1108/LHT-03-2017-0062

Rogers, R. (2004). Information politics on the Web. Cambridge, Massachusetts \& London, England: The MIT Press. https://doi.org/10.1108/00220410610673927

Rottenberg. C. (2018). The rise of neoliberal feminism. Oxford: Oxford University Press.

Silveirinha, M. J., Simões, R. B., \& Filgueiras, T. (2019). Him too? Cristiano Ronaldo and the news coverage of a rape case allegation. Journalism Practice. https://doi.org/10.1080/17512786.2019.1693279

Simões, R. B., \& Silveirinha, M. J. (2019). Framing street harassment: Legal developments and popular misogyny in social media. Feminist Media Studies, 1-17. https://doi.org/10.1080/14680777.2019.1704816

Soon, C. (2013). Collective action "going digital": Overcoming institutional and micro-structural constraints through technology use. JeDEM-eJournal of eDemocracy and Open Government, 5(2), 200-213. https://doi.org/10.29379/jedem.v5i2.220

Sundén, J., \& Paasonen, S. (2018). Shameless hags and tolerance whores: Feminist resistance and the affective circuits of online hate. Feminist Media Studies, 18(4), 643-656. https://doi.org/10.1080/14680777.2018.1447427

Thornham, S. (2007). Women, feminism and the media. Edinburgh: Edinburgh University Press.

Turley, E., \& Fisher, J. (2018). Tweeting back while shouting back: Social media and feminist activism. Feminism \& Psychology, 28(1) 128-132. https://doi.org/10.1177/0959353517715875

Youngs, G. (2005). Ethics of access: Globalisation, feminism and information society. Journal of Global Ethics, 1(1), 69-84. https://doi.org/10.1080/17449620500103849

Youngs, G. (2015). Digital transformations of transnational feminism in theory and practice. In R. Baksh \& W. Harcourt (ed.), The Oxford Handbook of Transnational Feminist Movements (pp. 857-870). Oxford, New York: Oxford University Press.

Walker, J., \& Palacios, C. (2016). A pedagogy of emotion in teaching about social movement learning. Teaching in higher education, 21(2), 175-190. https://doi.org/10.1080/13562517.2015.1136280

Walker, J., \& Butterwick, S. (2019). What have we learned? Feminism and social movement learning. In: Proceedings of the 38th CASAE Annual Conference (pp. 473-479). Retrieved May 7, 2021, from https://www.dropbox.com/s/04lcxsvmvek8kkh/2019_CASAE_Proceedings.pdf?dl=0

Welton, M. R. (1993). Social revolutionary learning: The new social movements as learning sites. Adult Education Quarterly, 43(3), 152-164. https://doi.org/10.1177/0741713693043003002

Zielińska, M., Kowzan, P., \& Prusinowska, M. (2011). Social movement learning: From radical imagination to disempowerment? Studies in the Education of Adults, 43(2), 251-267. https://doi.org/10.1080/02660830.2011.11661616 